\title{
BÓG ŁASKAWY. W STRONĘ BARDZIEJ PERSONALISTYCZNEJ CHARYTOLOGII
}

\section{TRYNITARNO-PERSONALIST YCZNY DYNAMIZM BOŻEJ LASKAWOŚCI}

Bóg łaskawy jest Trójcą Osób. Obdarza łaską w Chrystusie. W Nim wybrał nas i przeznaczył dla siebie (por. Ef 1, 4-6). W Pawłowym tekście odczytujemy trynitarny porządek samoudzielania się. Apostoł narodów mówi o wybraniu, o pełnym miłości odniesieniu Boga do człowieka. Te słowa stanowią zachętę do spojrzenia na tajemnicę łaski w aspekcie trynitarnym i personalistycznym. Takie ujęcie odpowiada zarówno potrzebie uwzględniania prawdy o Trójcy Świętej, jak i postulatowi jak najściślejszego jej zakorzenienia w Piśmie Świętym, czy wreszcie personalizmowi naszej epoki.

Współcześni autorzy zwracają uwagę, że obecna teologia skłania się raczej ku mówieniu o „osobie” niż o „,naturze” postuluje stosowanie terminów bliższych Biblii i mniej reistycznych niż np. „nadprzyrodzoność”. Zgodnie z tym nastawieniem „łaska” zyskuje wymiar bardziej teocentryczny i personalistyczny. Jest ujmowana nie jako „rzecz”, ale jako dynamiczne udzielanie się Boga człowiekowi

${ }^{1}$ Por. Z. K ij a s, Traktat o Duchu Świętym i łasce, w: E. A d a mia k, A. C z a ja, J. M a j e w s k i (red.), Dogmatyka. T. 4, Warszawa 2007, s. 512n. 
z miłości ${ }^{2}$ Zasługą św. Augustyna, a później scholastyki, było dostrzeżenie, że człowiek nie może sam wejść na wyżyny Bożego bytu, i opisanie łaski w kategoriach wartości, która sprawia zmianę statusu ontycznego osoby ludzkiej i pozwala skutecznie odpowiedzieć na Boże wezwanie, tj., zaangażować się w zbawienie własne i innych.

Za św. Tomaszem z Akwinu teologia przyjmowała antropologiczny punkt wyjścia przy omawianiu tematu łaski. Natomiast wychodząc do misterium Boga łaskawego, odczytujemy, jaki jest Bóg względem człowieka, którego nie tylko stwarza, ale dźwiga, ratuje, obdarza, czyni pięknym. Gdy prosimy, ,aby kierowała nami łaska, a nie nasze upodobania”, wiemy, że „upodobania”, poruszenia, emocje, a nawet pewne preferencje rozumu nie powinny kierować decyzjami osób. Nie mogłaby tego czynić także łaska, gdyby była jedynie jakimś duchowym mechanizmem, rzeczywistością choćby wzniosłą i dobrą, ale nieosobową. Coś nie powinno kierować kimś. „Łaska” to jednak metonimia Tego, którego kierownictwu chcemy i powinniśmy się poddać - Boga łaskawego.

Św. Jan Paweł II pragnął, by zasada pierwszeństwa łaski w życiu chrześcijańskim była wyraźnie ukazywana (por. NM 38). Rozważając istotę łaski, dostrzega w niej dar, który ma źródło w trynitarnym życiu Boga. „To sama boskość zaszczepiona w duszy”3. Do porządku tego samoudzielania się Stwórcy należy wybranie do uczestnictwa w Bożym synostwie i zbawieniu, czyli zaczyn świętości określany jako nowe człowieczeństwo (por. RM 8).

\section{I.1. TRYNITARNY PORZĄDEK LASKI}

Boże działanie jest łaskawe. Wypływa z hojności i dobroci Stwórcy, z Jego miłosierdzia i łaskawości. Bóg udziela się odpowiednio do tego, jaki jest. Jest Trójcą i jest Miłością, Prawdą i Życiem. Prawda, miłość

2 Tamże, s. 502.

${ }^{3}$ K. W oj t y ł a, Myśli o Niepokalanym Poczęciu, w: Tenże, Aby Chrystus się nami postugiwat, Kraków 1979, s. 75. 
i życie stanowią zatem wyznaczniki Bożej przychylności - łaski udzielanej człowiekowi.

\section{I.1.1. Miłość}

W darze łaski chodzi przede wszystkim o miłość. Człowiek nie ma przecież miłości z siebie. Całą zdolność miłowania otrzymuje od Boga. Owszem, został stworzony jako dobry i może spełniać to, co dobre, ale właśnie dzięki temu, że tak został stworzony. Dlatego Apostoł stawia retoryczne pytanie: „Cóż masz, czego byś nie otrzymał?” (1 Kor 4, 7). Jednakże, w jaki sposób człowiek może miłować Boga? Jak ma obdarzyć miłością Tego, który jest jej Źródłem? Synod w Orange odpowiada, że miłość ku Bogu jest Jego darem4.

W Bogu wszystko jest osobowe. Ojciec miłuje Syna z siebie. Syn miłuje Ojca z siebie, z tej samej Bożej natury. Ich miłość nie jest zjawiskiem. W Bogu nie ma nic nieosobowego. Ich miłość jest Osobą. To Duch Święty. W ten sposób Bóg Trójca jest Miłością. Jest komunią Osób. Człowiek miłuje Ojca wraz z Synem, dzięki przybranemu synostwu. To właśnie jest ów dar nadprzyrodzony, łaska uświęcająca. W tym porządku miłowania uczestniczy w działaniu Ducha Świętego, bo to właśnie Duch - Miłość włącza osoby ludzkie w trynitarną komunię. To w Nim Bóg udziela się człowiekowi. Na tym polega świętość - sakralność życia chrześcijańskiego; obecnego i przyszłego. Więcej, piękno tego miłowania Boga, z Bogiem i w Bogu, wyrażone greckim określeniem łaski (charis), odzwierciedla ład wieczności.

Św. Jan Paweł II opisuje ową łaskawą, pełną miłości inicjatywę Boga. Czyni to zwłaszcza w encyklikach Dives in misericordia (DM) i Dominum et vivificantem (DeV). Mówi w nich o Bogu, który jako Trójca jest podmiotem łaski, o udzielającej się miłości Boga i o Jego dziełach. W Chrystusie ukazała się łaska nieskończona, czyli miłość Ojca, dar, źródło życia. Jej ujawnienie się w dziejach dokonało się za sprawą Ducha Świętego (por. DeV 54). Zesłanie Parakleta wyznacza

${ }^{4}$ Por. Synod w Orange, kanon 25, S. G ł o w a, I. B i e d a (red.), Breviarium fidei. Wybór doktrynalnych wypowiedzi Kościoła, Poznań 1989, VII, 36. 
nowy początek udzielania się Trójjedynego Boga za sprawą Jezusa Chrystusa (por. DeV 14). Święty Papież przypomina, że to Duch Święty jest miłością i Darem nie-stworzonym, z którego wypływa wszelkie obdarowanie stworzeń, a więc obdarowanie łaską (darem stworzonym) przez całą ekonomię zbawienia (por. DeV 10). To Duch Święty obraca smutek w radość (por. DeV 24). Jan Paweł II zwraca uwagę na to, że chociaż wiemy o działaniu Ducha Świętego, jest ono ze swej istoty niewidzialne, duchowe, odbywa się przecież w tej przestrzeni, w jakiej człowiek zyskuje rzeczywisty, bez pośrednictwa stworzeń, przystęp do Niewidzialnego Ojca (DeV 54). Również Benedykt XVI utożsamia trynitarny porządek udzielania miłości z darem łaski. Caritas jest łaską (por. CiV 5). Źródło miłości Ojca do Syna w Duchu Świętym spływa na nas z Syna, rozlane przez Ducha Świętego. Człowiek, otrzymawszy ten dar, staje się podmiotem miłości i narzędziem Ducha Świętego. Miłuje mocą, którą ma od Boga.

\section{I.1.2. Prawda i przybrane synostwo}

W Prologu Ewangelii św. Jana czytamy o chwale, jaką Jednorodzony otrzymuje od Ojca pełen łaski i prawdy (por. J 1, 14).To zwięzłe zdanie łączy pojęcie łaski ze ścisłym kontekstem trynitarnym, ale także z prawdą obecną w sercu Trójcy. Chrystus sam przedstawia siebie jako Prawda, ale również Duch Święty nosi miano Ducha Prawdy. Janowe słowa mówią więc o objawieniu tajemnicy Ojca przez Syna, ale także i przez Ducha Świętego, bo przecież chodzi tu o przekaz nie tylko zewnętrzny, ale o taki, który angażuje całego człowieka; mówi do jego „serca” (por. Oz 2, 16; J 1, 17 - 18). Ukazanie prawdy trynitarnego misterium nie wyczerpuje się w wymiarze epistemologicznym. Stanowi wezwanie do przyjaźni, w której „głębokości Boga" zostają otwarte dla człowieka. Obdarza zdolnością do zawarcia przymierza (por. DeV 33).

„Łaska Pana naszego Jezusa Chrystusa”, o której mówi liturgia, to wysłużone Jego ofiarą ,upodobnienie do obrazu Syna” (por. Rz 8, 29) i powołanie do Jego chwały. Tylko ,przybrane synostwo”, czyli udział w Chrystusowym synostwie, może wprowadzić człowieka 
w głębię komunii trynitarnej (por. DeV 22). To „upodobnienie do Chrystusa" jest dziełem Ducha Świętego równoznacznym z łaską uświęcającą. Rodzi się w ludziach dzięki Chrystusowi, gdy Bóg wysyła do serc Ducha Syna Swego (por. DeV 52). Ten sam Duch, który stał się najpierw darem dla Syna w głębokościach Trójcy i darem dla Chrystusa - Mesjasza w misterium chrztu w Jordanie, dopełnia Jego dzieło jako Osoba - Dar (por. DeV 22). Męka Chrystusa otwiera Duchowi Świętemu drogę do wnętrza człowieka (por. DeV 42). Duch ten przenika i wypełnia głębię serc (por. DeV 45). Jan Paweł II zaznacza, że to wewnętrzne działanie nie odbywa się poza świadomością osoby. Przeciwnie, Duch Święty likwiduje wszelkie zło, ale i daje je poznać. Rodzi dobro i kieruje ku dobru (por. DeV 42).

Przybrane synostwo zawiera wezwanie do życia łaski. To nowe otwarcie Bożego ojcostwa, w którym Duch Święty przychodzi jako Duch Prawdy. Ojciec zwraca się do człowieka z tą samą miłością, jaką miłuje Syna i odwołuje się do tego ,podobieństwa', jakim jest właściwe osobie ludzkiej pragnienie prawdy. Duch Święty porusza człowieka właśnie jako Duch Prawdy, w której Bóg daje się poznać (por. RH 9). Dlatego ten, kto odpowiada na dar łaski, może powtórzyć za św. Pawłem: „Wiem, komu uwierzyłem” (2 Tm 1, 12).

Nieuchwytne działanie Ducha Prawdy to coś znacznie więcej niż „łaska zewnętrzna”, związana z samym oświeceniem umysłu. Duch Święty spotyka się z wewnętrzną otwartością na prawdę i pomaga kształtować siebie według prawdy, tj., w sposób ostatecznie niezależny od wszystkiego poza prawdą, bez lęku, bez żadnych błędnych i zwodniczych kryteriów (por. RH 9).

Chrystus Odkupiciel znajduje się w centrum Bożej łaskawości i objawia w pełni człowieka samemu człowiekowi (RH 10). Św. Jan Paweł II nie rezygnuje z antropologicznego kierunku spojrzenia, tego samego, który zdominował Tomaszowe ujęcie łaski. Antropologia, a raczej personalizm świętego Papieża, pozostaje jednak w ścisłym związku z misterium Trójcy Świętej. Odnosi się do źródła Bożej łaskawości, jakim jest pokój i piękno trynitarnej komunii. Ze stwórczej radości, objawiającej się przy obdarzeniu bytów istnieniem i pięknem, bierze się nieskończona hojność i przychylność, dzięki którym 
człowiek staje się zdolny do miłości w sensie teologicznym; do więzi i przymierza na wzór i ,podobieństwo” Osób Boskich.

\section{I.1.3. Życie}

Nieograniczoność Bożej przychylności sprawia, że miłość i prawda mają być udzielane człowiekowi bez końca. Cóż by to bowiem była za łaskawość, gdyby miała skapitulować wobec śmierci? Bóg, który jest Ojcem, doprowadza przybranych synów do udziału we własnym życiu. Kto miłuje, pragnie obdarzać sobą (por. DM 7). Dlatego przez Ducha Ożywiciela Bóg udziela się ludziom, zaszczepiając w nich zadatek życia wiecznego (por. DeV 1).

Łaska to zadatek nowego życia. Duch Święty jest Miłością i Darem. Jan Paweł II stosuje tu pojęcia daru niestworzonego i stworzonego w kontekście trynitarnym. Pisze, że w nadobfitości Daru niestworzonego, jakim jest Duch Święty, ma swój początek dar stworzony - udział w Bożej naturze; życie ludzkie zyskuje nowy wymiar dzięki dostępowi do Ojca w Duchu Świętym (por. DeV 52). Ojciec Święty zwraca uwagę na trynitarną formułę chrztu, która oznacza, że moc tego sakramentu włącza w życie Trójjedynego Boga, ponieważ niesie w sobie uzdolnienie i powołanie do udziału w nim (por. DeV 9).

\section{I.2. WYBRANIE}

„Bóg wybrał nas przed założeniem świata, abyśmy byli święci i nieskalani przed Jego obliczem" (Ef 1,4). Teologia łaski wielokrotnie mierzyła się z pojęciem predestynacji. Kościół katolicki jednoznacznie odrzucił stwierdzenie, że Bóg kogokolwiek przeznacza na potępienie ${ }^{5}$. A jednak tych, ,których przeznaczył, tych też powołał, a których powołał - tych też usprawiedliwił, a których usprawiedliwił - tych też obdarzył chwałą" (Rz 8, 30). Zamiast obciążonego błędnymi konotacjami pojęcia ,predestynacji” może lepiej byłoby w tym miejscu mówić o „destynacji”. To słowo wydaje się trafniej

\footnotetext{
5 Por. np. XV Sobór w Konstancji, Breviarium fidei..., dz. cyt., VII, 56.
} 
oddawać sens ,przeznaczenia do czegoś”, odpowiedniego do zamysłu Stwórcy, ale przecież nie przesądzonego z góry, pozostawionego do decyzji zainteresowanego. Jednakże ,przeznaczenie”, czy „destynacja" to także określenia, które zbyt łatwo przywodzą na myśl świat rzeczy. Słowo „wybranie” wskazuje na osobę, na odniesienie wobec osoby z zaangażowaniem, życzliwością, a nawet swego rodzaju rezygnacją z bytowania bez wybranego. Co to jednak za wybranie, które obejmuje wszystkich? Każdy jest wybrany do zaplanowanej przez miłość Bożą niepowtarzalności. Wybranie do zbawienia jest to samo dla wszystkich, ale zarazem jedyne i niepowtarzalne dla każdego, ponieważ zawsze dotyczy osoby. Bóg miłuje tak samo, ale każda osoba jest dla Niego jedyna i niepowtarzalna.

Bóg udziela się człowiekowi, bo przedwiecznie ogarnia go swoim pełnym przyjaźni, oblubieńczym wyborem. To coś więcej i coś innego niż tylko plan wobec osób stworzonych. Św. Jan Paweł II odnosi do tajemnicy wybrania słowa proroka: „Ukochałem cię odwieczną miłością, dlatego zachowałem dla ciebie łaskawość" (Jr 31, 31). Podkreśla, że wybranie dotyczy każdego człowieka (por. DM 4). Natomiast Benedykt XVI na początku encykliki Caritas in veritate pisze, że miłość w prawdzie to siła napędowa rozwoju każdego człowieka, która ma swój początek w Bogu - odwiecznej Miłości i absolutnej Prawdzie (CiV 1). Bóg pełen łaskawości daje siebie. Ze swojej własnej Miłości i Prawdy udziela osobom ludzkim wewnętrznej mocy, by mogły wzrastać ku świętości.

W Trójcy Świętej jedno istnienie i jedna miłość stanowi własność i treść bytu Osób. Wobec człowieka dar życia jest udzielany jednokierunkowo - od Żyjącego Boga. Jednocześnie, dar tego Życia, które jest własne Boga-Trójcy, charakteryzuje się otwartością na wzajemność i wywołuje wzajemne relacje. Wszelka wzajemność osób w eklezjalnej komunii stanowi vestigium udzielania się Bożego życia.

Kiedy Bóg-Miłość udziela się człowiekowi, to wewnętrzne spotkanie z Trójosobowym stanowi ,poruszenie łaski”, o którym mówi teologia. Jest ono niedostrzegalne, wewnętrzne, a jednak ukierunkowane „na zewnątrz”, ku innym. Okazuje się zatem eklezjotwórcze i wspólnototwórcze. Bóg tak porusza człowieka, że ów staje się 
miłującym, tj., zyskuje od Ducha Świętego zdolność miłowania i to miłowania włączonego w zbawcze dzieło. Łaska stworzenia spowodowała, że człowiek stał się partnerem Stwórcy w działaniu wobec świata stworzeń. Dlatego mógł nadawać nazwy zwierzętom, mógł panować nad światem i porządkować go w sposób ludzki. Łaska Nowego Przymierza uzdalnia do wprowadzania ładu w przestrzeni duchowej. Ktoś przeniknięty tą łaską uczestniczy w życiu Trójcy. Wraz z Chrystusem miłuje i ofiarowuje siebie. Bóg wybrał wszystkich do wspólnoty z sobą. Do wspólnoty w komunii życia i miłowania. Każdy ma zatem swoje szczególne wybrane miejsce w planie zbawienia, a najbardziej wyjątkowe i niepowtarzalne - Maryja, pełna łaski Matka Zbawiciela (RM 7).

\section{I.3. NOWE CZLOWIECZEŃSTWO}

Rzeczywistość łaski uświęcającej oznacza nową jakość bytu, którą za św. Pawłem teologia określa jako „przybrane synostwo”. Zarówno Jan Paweł II jak i Benedykt XVI podkreślają, że chodzi tu o osobową więź z Chrystusem. Zjednoczenie z Nim to wewnętrzna, przemieniająca moc tajemnicy, w której rodzi się nowy człowiek; to zasada nowego życia, które nie niszczeje i jest ostatecznym powołaniem człowieka (por. RH 18). Również Benedykt XVI łączy moc łaski z powołaniem, z wezwaniem do świadomego upodabniania się do Chrystusa - Syna Ojca (por. VD 22). Łaska dopełnia i udoskonala naturę. Jan Paweł II rozwija tę myśl w kategoriach personalizmu. Pisze, że w Chrystusie człowiek osiągnął i osiąga godność, która jest godnością łaski Bożego przybrania, a równocześnie wewnętrznej prawdy człowieczeństwa (por. RH 11). Papież zwraca też uwagę na rozwój życia łaski dzięki sakramentom, a szczególnie Eucharystii. To w niej wyraża się nasz nowy byt, w którym każdy jako uczestnik tajemnicy Odkupienia ma dostęp do owoców synowskiego „pojednania" z Bogiem (por. RH 20).

Powracające przez wieki zagadnienie predestynacji, spory o łaskę wystarczającą i skuteczną w jakiś sposób krążą wokół kwestii, czy rzeczywiście Pan Bóg jednym daje łaskę, a innym nie, bądź udziela 
jej ,zbyt skąpo”. W jakiś sposób odzwierciedla to pytanie postawione przez uczniów Chrystusa: „Panie, cóż się stało, że nam się masz objawić, a nie światu?” (J 14, 22). Pan Jezus wyjaśnia: „Jeśli Mnie kto miłuje, będzie zachowywał moją naukę, a Ojciec mój umiłuje go, i przyjdziemy do niego, i będziemy u niego przebywać" (J 14, 23). Wewnętrzne działanie Boga, ,zamieszkanie Trójcy” wiąże się z wzajemnością, z odpowiedzią na miłość. Więcej, z przytoczonych słów wynika, że Boga poznaje się przez miłość i przebywanie z Nim. Poznanie dzięki komunii to antycypacja wieczności - widzenia uszczęśliwiającego. Karl Rahner pisze, że miłość Boża w wolnej łaskawości stwarza w duszy pustkę, którą sama chce wypełnić sobą, bo Bóg nie ofiarowuje jakiegokolwiek daru, ale siebie ${ }^{6}$. Czy nie właściwsze byłoby jednak nazwanie tej przeznaczonej dla Boga przestrzeni nie „pustką”, ale „głębią”, jak uczynił to choćby św. Jan Paweł II w pięknym przemówieniu w Gdyni w 1987 r.? ${ }^{7}$

Jeśli już zatem mówić o przeznaczeniu, to w ten sposób: Bóg przeznaczył nas dla siebie. Wewnętrzne ,poruszenie łaski” ukazuje człowiekowi tę właśnie prawdę o Bogu i o samym człowieczeństwie. Jan Paweł II pisze, że modlitwa to objawienie głębi ludzkiego serca, którą tylko Bóg może wypełnić Duchem Świętym. To w niej „nowy człowiek" za sprawą Ducha Świętego doświadcza udziału w życiu Boga (por. DeV 65). W tym nowym człowieczeństwie wzajemność miłości nie byłaby możliwa, gdyby nie została zachowana odrębność osób. Bóg i człowiek pozostają sobą, a stają się jednym (DC 10). Człowiek osiąga tak wielką godność, że pozostaje sobą w obliczu Boga, który wypełnia go, ale nie umniejsza i nie pochłania.

Bóg obdarza łaską nadobficie. Jest nieskończony, a więc nieskończony także w łaskawości, w obdarzaniu życiem, które się nie

${ }^{6}$ Por. K. R a h ne r, Grundkurs des Glaubens. Einführung in den Begriff des Christentums, Freiburg im Breisgau 1976, s. 130. („Die Fülle Gottes diese Leere schaft um sich ihr selber mituzuteilen").

7 Por. J a n Paw eł II, Przemówienie do ludzi morza 11. czerwca 1987, w: Trzecia pielgrzymka Jana Pawła II do Polski. Przemówienia, dokumentacja, Poznań - Warszawa 1987, s. 112. 
wyczerpie. Przyjęcie daru nie odbywa się jednak biernie. Wymaga czynu. Z własną ograniczonością, grzesznością zwycięża ten, kto potrafi przyjąć dar Bożego życia w Duchu Świętym (por. DeV 55).

\section{I.4. UCZYNKI LASKI}

Elementem, jakże istotnym, zleconego przez Boga „czynienia sobie ziemi poddaną" (por. Rdz 1, 28) jest kształtowanie siebie, praca nad ,glebą własnego człowieczeństwa”. Polecenie to nie zostaje zawieszone nawet po grzechu Kaina: „grzech leży u wrót i czyha na ciebie, a przecież ty masz nad nim panować" (Rdz 4, 7). Człowiek został nieodwołalnie zaproszony do współdziałania z Bogiem w kształtowaniu nie tylko świata zewnętrznego, ale nade wszystko siebie. Ponieważ sam nie dałby sobie rady, Bóg udziela mu wskazówek. Św. Tomasz mówi, że tylko z pomocą łaski możemy dokonywać czynów przekraczających możliwości natury ${ }^{8}$. Co to znaczy? Pogańska sprawiedliwość wznosiła się nieraz na wyżyny szlachetności i heroizmu. Sokrates był w stanie oddać życie za prawdę. Tu chodzi jednak o coś więcej; o kształtowanie siebie na wzór zawartego w akcie stwórczym ,podobieństwa” do Boga, o upodobnienie się do Chrystusa, naśladowanie Go dzięki Duchowi Świętemu.

To dzięki łasce uczynkowej człowiek wchodzi w nowość życia. Staje się „mieszkaniem Trójcy”. W komunii łaski rozszerza się wewnętrzna przestrzeń życiowa; człowiek żyje w Bogu i dla Boga. Żyje według Ducha i dąży do tego, czego chce Duch Święty (por. DeV 58). Udzielanie się Boga człowiekowi stanowi zatem wezwanie, by ów stawał się uczestnikiem prawdy i miłości, która jest w Bogu; wezwanie do przekraczającej ludzkie siły aktywności (por. DM 7).

Ujmując rzecz statycznie można powiedzieć, że ktoś dobry to ten, którego czyny są dobre. W ujęciu personalistycznym brzmi to nieco inaczej: osoba staje się dobra przez czyn ${ }^{9}$. Przez czyn dobry człowiek staje się dobry. Dlaczego, skoro, nie ma dobra z siebie? Czy

\footnotetext{
${ }^{8}$ Por. STh I - II, q 109, a 2.

9 Por. K. Woj tyła, Osoba i czyn, Kraków 1969, s. 104.
} 
nie przypomina to próby przemieszczenia własnego środka ciężkości swoimi silami, co jest niemożliwe z punktu widzenia fizyki?

Źródło dobra jest w Bogu. Przychylność Stwórcy okazuje się w kolejnych etapach historii zbawienia łaską uczynkową, uświęcającą... Ten sam Bóg łaskawy, hojny w swojej dobroci, działa. Punkty zwrotne indywidualnej historii spotkania człowieka i udzielającego się Boga to chrzest, sakrament pojednania, Eucharystia. Nawrócenie jest dziełem łaski, w którym człowiek ma siebie samego w pełni odnaleźć (por. RH 12). Ma stawać się przez własny czyn, ale nie samowolnie. Według prawdy, pod kierunkiem Ducha Świętego rozpoznaje drogę własnego stawania się tym, kim ma być. Staje się sobą, gdy żyje według prawdy. Przypomina to słowa soborowej konstytucji mówiące, że człowiek odnajduje siebie przez bezinteresowny dar z siebie, czyli po prostu przez miłość (por. KDK 24). W dziele łaski współtworzy kształt własnego człowieczeństwa przez miłość i według prawdy.

Przez czyn dobry można wzrastać w dobru, ale żaden czyn ludzki nie przyniesie sacrum udziału w życiu Boga Trójjedynego. Do udziału w życiu Boga człowiek staje się zdolny przez czyn Chrystusowy. Św. Paweł mówi o swoich dokonaniach: ,pracowałem (...), nie ja, co prawda, lecz łaska Boża ze mną" (1 Kor 15, 10). Czyn dokonany wraz z Chrystusem, włączony w jego miłość ku Ojcu to zapowiedź wieczności. Jego treść stanowi to samo, co będzie istotą nagrody - współudział z Chrystusem. Nagrodą za czyny spełniane razem z Chrystusem jest Jego pełna obecność, nagrodą za przebywanie w obecności Boga na modlitwie - widzenie uszczęśliwiające. W ten sposób, kto czyni dobro, ubogaca się dobrem. Kto współdziała z udzielającym się Bogiem, ma udział w Jego życiu.

\section{I.5. ASPEKT EKLEZJALNY}

Otrzymanie nienależnej godności w darze łaski obrazuje przypowieść o synu marnotrawnym, któremu już nic się nie należało od ojca (por. Łk 15, 11nn). W darze przebaczenia syn nie otrzymuje czegoś od ojca, ale wszystko. Może na powrót mieszkać w jego domu. 
Domownicy ojca stają się jego domownikami, a drugi syn ojca znowu jego bratem (por. Łk 15, 32). Łaskawe udzielanie się Boga ma znaczenie wspólnotowe, eklezjalne.

Skarb człowieczeństwa, pogłębiony o niewymowną tajemnicę Bożego synostwa, o misterium łaski przybrania za synów, to potężna siła jednocząca Kościół od wewnątrz (por. RH 18). Kościół zaczyna się od chrztu, bo składa się z ochrzczonych.

Bóg w swojej hojności daje nadobfitość łaski, która służy budowaniu komunii eklezjalnej. Bezinteresowny dar z siebie, każdy czyn zasługujący ubogaca Kościół. Mówił o tym św. Jan Paweł II w Starym Sączu ${ }^{10}$.

Wewnętrzne obcowanie z Bogiem to niewyczerpane źródło prawdy o własnym człowieczeństwie. Jej poznanie i realizacja za sprawą Ducha Świętego przynosi nie tylko własne uświęcenie, stanowi też zarzewie, za pomocą którego Bóg przetwarza świat ludzki od wewnątrz (por. DeV 59; KL 61; DA 13). Wspaniały przykład tego mamy w osobie Matki Najświętszej, która, jako pełna łaski i pośredniczka łask, jest wzorem i zarazem wspomożycielką.

\section{LASKI PELNA. WZORCE DZIALANIA BOŻEJ LASKAWOŚCI}

Przykłady działania Bożej łaskawości widzimy w doświadczeniu osób nią obdarzonych. Wśród nich szczególne miejsce zajmuje Maryja.

Charytologia rozważała często sytuacje graniczne, a nawet ,podprogowe”. Skupiała się na grzechu pierworodnym, usprawiedliwieniu, czyli momencie wydobycia z grzechu, dotykała sytuacji braku łaski i początku udzielania się Boga. Maryja nazwana przez anioła od razu „pełną łaski” to wzorzec charytologiczny. W Jej osobie oglądamy spełnienie drogi człowieka obdarzonego obecnością Boga, przepojonego więzią z Nim. Pełna łaski stanowi wzór cnót teologalnych,

${ }_{10}$ Por. J a n P a w eł II, Homilia z 16.06. 1999, w: J. G ó r n y (red.), VII pielgrzymka Jana Pawła II do ojczyzny, Olsztyn 1999, s. 228. 
wiary, nadziei i miłości (RM 2). Bez Niej znalibyśmy grzeszność i grzech, a także różne drogi łaski i uświęcenia, ale nie znalibyśmy pełnej świętości, do jakiej człowiek został powołany.

\section{II.1. INICJATYWA BOGA}

Dar łaski jest absolutnie darmowy. Pochodzi z inicjatywy Boga. To Stwórca szuka człowieka po grzechu i pierwszy się do niego zwraca (por. Rdz 3, 9).

Zwiastowanie Maryi następuje w sześć miesięcy od poczęcia Jana Chrzciciela, w sześć miesięcy od startu drogi Nowego Przymierza. To Bóg przygotował w domu Zachariasza preludium Wcielenia (por. Łk 1, 16). Sama Maryja niczego się nie spodziewa. Jest zaskoczona, „zmieszana”. Słowo objawienia, słowo prawdy odkrywa w Niej źródło radości - obecność Boga (por. Łk 1, 28). To, że jest pełna łaski, Maryja poznaje nie na skutek własnej refleksji, ale objawienia. Bez uprzednich zasług została odkupiona „w sposób wznioślejszy”; od swego poczęcia obdarzona nowym życiem w Bogu (por. RM 10). Absolutna inicjatywa Boga wobec Niej wyraża najdobitniej prawdę o zupełnej darmowości łaski1". „Charis” to łaska i wdzięk. Piękno Maryi stanowi dla ludzkości niezmienny znak i potwierdzenie wybrania potężniejszego od wszelkiego zła (por. RM 11). W pełnym miłości i łaski wybraniu Maryi przez Boga możemy odczytać pozytywny sens przeznaczenia, rozumianego raczej jako destynacja niż prede-

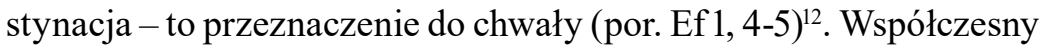
teolog mówi, że zbawienie Maryi polegało na przekształceniu Jej egzystencji w oparciu o wewnętrzną łaskę ${ }^{13}$. Czy jednak można myśleć o przekształceniu, gdy pełna łaski została stworzona od początku w nowości życia łaski?

11 Por. J. K róli k o w s k i, Bogiem sławiena Maryja, Niepokalanów 2015, s. $42 \mathrm{n}$.

12 Tamże, s. 43.

13 Por. J. K r ól i k o w s k i, Bogurodzica Dziewica, Niepokalanów 2013, s. 209. 
Bóg łaskawy zwraca się do człowieka z miłością. Czyni to w sposób najbardziej odpowiedni i czytelny dla danej osoby. Do Maryi, wybranej na Matkę Odkupiciela, przychodzi Archanioł z delikatnością i kurtuazją. Impet Szawła dyszącego gniewem i chęcią zabijania zostaje powstrzymany przez gwałtowny upadek z konia i utratę wzroku (por. Dz 9, 3nn). Sprawiedliwość i pobożność Korneliusza napotyka na zaskakującą inicjatywę Boga (Dz 10, 4). To, że anioł zwraca się do niego po imieniu i z szacunkiem, świadczy o wybraniu i dostrzeżeniu jego postawy, o pełnym troskliwości wezwaniu osoby.

\section{II.2. SPOTKANIE DUCHOWE}

Udzielanie się Boga dotyczy niedostępnej dla świata zewnętrznego głębi jestestwa; samego „serca” osoby. Jest to spotkanie duchowe i osobiste, nawet wówczas, gdy z relacji Pisma Świętego dowiadujemy się o pośrednictwie anioła.

Ewangelista, opisując zwiastowanie, mówi, że „Anioł wszedł do Niej" (Łk 1, 28). Nikt z zewnątrz o tym nie wie. Maryja znajduje się w niewyobrażalnej bezpośredniości mocy Ducha Świętego.

Pędzącego do Damaszku Szawła olśniewa światłość. To sam Chrystus - Światłość ludzi (por. J 1, 4), światło na oświecenie pogan (por. Łk 2, 32). Światło to również symbol łaski, daru, który prowadzi do szczególnej zażyłości z Bogiem ${ }^{14}$. Ojciec Święty Benedykt XVI zauważa, że Pan Jezus odnosi ten właśnie symbol do siebie i do swoich uczniów, mówi: „Ja jestem światłem” i „Wy jesteście światłem". Chodzi o to, że On w nas zapala swoje światło w sakramencie chrztu $^{15}$. Napełnia nas sobą.

Szaweł słyszy głos z nieba. Niebo to metonimia Boga. Zjawisko „głosu” przypomina scenę znad Jordanu podczas chrztu Jezusa. To

${ }^{14}$ Por. J. K róli k ow s k i, Bogiem sławiena..., dz. cyt., s. 47.

15 Por. B e nedykt XVI, Vigil young people, address of his holiness Benedict XVI, Fair, Freiburg im Breisgau, Saturday, 24 September 2011; www.vatican.va/.../speeches/2011/september/documents/ hf_ben-xvi_spe_20110924_vigil-freiburg_en.html - 13k - 2011-09-24. 
objawienie Boga. Dyskurs Szawła z „głosem” jest niezrozumiały dla otoczenia. „Głos” to interwencja niedostępnego Boga - niczym nie poprzedzona, nie zapowiedziana, następująca bez zasług Szawła, a nawet wbrew temu, na co zasłużył. „Głos” daje się usłyszeć i zrozumieć w samej ,głębi” osoby, bez potrzeby zewnętrznego pośrednictwa stworzeń.

\section{II.3. GODNOŚĆ I PRAWDA}

W kulminacyjnym momencie dziejów Syn Boży przychodzi pełen łaski i prawdy (por. J 1, 14). Samoudzielanie się Boga człowiekowi przebiega według trajektorii łaski i prawdy, bo taki jest Bóg. Jest łaskawy i prawdziwy. Obdarzenie godnością nowego człowieczeństwa jest nierozłączne od prawdy o Bogu i o osobie obdarowanego. Dar łaski i prawdy zostaje zaoferowany darmo i uprzedzająco; to dar, który dopiero czeka na akceptację i odpowiedź.

Dar łaski niesie prawdę, która odsłania dyspozycję osoby. To nieodzowny punkt wyjścia do akceptacji daru nowego człowieczeństwa. W spotkaniu z osobowym Bogiem ujawnia się prawda o osobie obdarowanej i o godności, którą otrzymuje z łaskawości Bożej.

Archanioł, w postawie pełnej uszanowania, ukazuje Maryi Jej godność i status. Niepokalana słyszy, że może się radować, bo jest pełna łaski i że Bóg się Nią raduje. Anioł nie mówi tego, aby sprawić przyjemność. Każdy wzlot ku Bogu, nawrócenie, przyjęcie łaski, a w przypadku Maryi, podjęcie powołania dokonuje się w prawdzie.

„Pełna łaski” (kecharitomene) to jakby imię własne Maryi, które ma od Boga, imię, które mówi o Jej tożsamości, wyjątkowości, niepowtarzalności ${ }^{16}$. Matka Zbawiciela jest tym, kim jest, jest sobą, bo jest pełna łaski.

„Pełnia łaski” to coś więcej niż „wyjściowa” bezgrzeszność Adama. Maryja była od początku zjednoczona ze Słowem Przedwiecznego, już wtedy miała udział w miłości Trójcy, a więc posiadała

\footnotetext{
${ }_{16}$ Por. Tom as z z A kw in u, Wykład Pozdrowienia Anielskiego, czyli „Zdrowaś Maryjo”, w: Tenże, Dzieła wybrane, Kęty 1999, s. 9.
} 
to, co zawiera się w pojęciu łaski uświęcającej. Jej „imię” - Kecharitomene - mówi o wybraniu, które dokonało się przed założeniem świata, o tym, że została odwiecznie przez Ojca i Syna zawierzona Duchowi Świętemu. Dar spotyka się z wyjątkową postawą Obdarowanej. Prawda Jej osoby to pokorna otwartość w stronę „daru z wysokości” (por. RM 8) ${ }^{17}$. „Charis” to łaska i jednocześnie wdzięk. Niepokalanie Poczęta jest od początku święta i zdolna do dobra. Jej wewnętrzny ład dobra i miłości, harmonia woli i umysłu, słów i czynów są doskonałe. Zdanie „wszystka piękna jesteś Maryjo” ma sens teologiczny. Mówi o pełnym harmonii odniesieniu do Boga i stworzeń, a więc o pięknie ontycznym, a także o wspaniałości moralnej. Zapisane przez ewangelistów słowa Matki Najświętszej to wypowiedzi utkane $\mathrm{z}$ najszlachetniejszego materiału, jakim są fragmenty Pisma Świętego (por. VD 28), zaś piękno Jej postaci poświadczają objawienia prywatne ${ }^{18}$.

Duchowe piękno i świętość zespalają się w osobie Niepokalanej. „Magnificat" to wyraz radości pochodzącej od Ducha Świętego, który napełnia Maryję, radości antycypującej niebo. „Pełna łaski” uczestniczy w życiu Boga, jest zjednoczona z Trójcą Świętą, dlatego już na ziemi może się cieszyć radością świętych ${ }^{19}$. Zbawienie, którym została obdarzona, nie oznacza przecież czegoś zewnętrznego, ale napełnia Niepokalaną jako wewnętrzna łaska, integralna z Jej osobą. „Pełna łaski” nawet podczas ziemskiej drogi nie należała do świata, chociaż podlegała jego prawom. Jako Służebnica Pańska cieszyła się nowością człowieczeństwa poddanego rzeczywiście i bez reszty Duchowi Świętemu.

17 Por. B e n e d y k t XVI, Homily, Av. dos Aliados Square, Porto Friday, 14 May 2010; http://w2.vatican.va/content/benedict-xvi/en/homilies/2010/documents/ hf_ben-xvi_hom_20100514_porto.html.

${ }_{18}$ Por. J. K róli k ow s k i, Bogiem sławiena..., dz. cyt., s. 49.

19 Por. B e n e d y k t XVI, Conclusion of the month of May, Grotto of Lourdes in the Vatican Garden Thursday, 31 May 2012, http://w2.vatican.va/content/benedict-xvi/en/speeches/2012/may/documents/hf_ben-xvi_spe_20120531_mese-mariano. html. 
Imię wyraża tożsamość osoby. Określenie „pełna łaski” zawiera wszystkie tajemnice Maryi i stanowi punkt wyjścia dla Jej zadań w dziele zbawienia; staje się Matką Syna Bożego i Matką Kościoła, Królową świata i aniołów dlatego, że jest pełna łaski. Jej wniebowzięcie okazuje się ostatecznym wyrazem i zwieńczeniem tej „,pełni”, czy też pełnego zjednoczenia z Synem, który zwyciężył śmierć, pełnego udziału w komunii Trójjedynego Boga, czyli pełnego, doskonałego przyjęcia daru Jego łaskawości.

Poruszenie łaski odsłania prawdę osoby w sposób dla każdego właściwy. Korneliusz, poganin, odczuwa lęk wobec anioła - posłańca Nieznanego. Bóg znalazł upodobanie w postawie tego setnika (por. Dz 10, 4). Prawda o nim dotyczy jego pogańskiej uczciwości i pobożności, a jednocześnie tego, że od Boga nic się nikomu nie należy. Nadobfitość Bożej łaskawości sprawia, że Korneliusz zostaje obdarowany hojniej niż mógł się spodziewać.

Również w przypadku Szawła interwencja Boga daje mu w sposób namacalny poznać prawdę o własnej kondycji, o tym, że jest prześladowcą. Upadek uświadamia mu własną słabość i złudę dotychczasowej pewności siebie. W tajemniczej rozmowie Szaweł poznaje uprzedzającą dobroć Boga, który nie osądza, nie oskarża, nie stawia warunków, ale pyta: „Dlaczego mnie prześladujesz?” (Dz 9, 4). Pyta o rację postępowania. Odwołuje się do rozumu, zachęca do konfrontacji z prawdą. Pytanie o prawdę rozpoczyna drogę łaski. Szaweł nie zaprzecza ocenie swoich czynów, nie neguje tego, że jest prześladowcą (por. Dz 9, 5). Uznaje tego, z którym rozmawia, nazywa go „panem”. Nie odwraca się od Niego, ale chce Go poznać, pyta. Jezus przedstawia się. Dar łaski wymaga prawdy, jawności. W zdaniu: „Ja jestem Jezus” wykształcony faryzeusz może przecież odczytać deklarację bóstwa. Spotkanie na drodze do Damaszku okazuje się darem łaskawości Zbawiciela. Rozkaz „Wstań” (Dz 9, 6) przypomina Szawłowi o jego godności. Jezus daje się poznać nie tylko jako ten, który identyfikuje się z prześladowanym Kościołem. Jest Bogiem, który przywraca godność, ,podnosi nędzarza z prochu” (Ps 113, 7). Dotychczasowej postawie Szawła-prześladowcy przeciwstawia zbawczy plan ostatecznego dźwignięcia go aż do zmartwychwstania. 
Poznanie prawdy, wewnętrzna łaska prawdy i darowanie nowej godności wiążą się z dwoma biblijnymi symbolami: światła i płaszcza. Ten drugi symbol odpowiada teologicznemu pojęciu habitus, stosowanemu na określenie łaski rozumianej jako przymiot. Ów rozumiany biblijnie „płaszcz” to nie tylko zewnętrzne okrycie, ale ingerencja $\mathrm{w}$ faktyczną kondycję osoby. To symbol napełniającej wnętrze „mocy z wysoka”. Takie znaczenie miał choćby płaszcz Eliasza, wraz z którym Elizeusz otrzymał „dwie części ducha” wielkiego proroka. Izajaszowe słowa: „dusza moja raduje się w Bogu moim, bo mnie przyodział w szaty zbawienia, okrył mnie płaszczem sprawiedliwości" (Iz 61, 10) zapowiadają radość ze zbawienia, obejmującą całego człowieka, tę, którą daje Duch Święty.

Gdy ewangeliczny ojciec okrywa płaszczem syna marnotrawnego, który wrócił, aby być niewolnikiem, czyni to nie dlatego, aby ukryć nędzę swojego dziecka, ale by przywrócić mu godność syna. Przypowieść oddaje w ten sposób prawdę o rzeczywistej, ontycznej godności kogoś, komu odpuszczono grzechy i kto w tym momencie może uczestniczyć w życiu Boga; jest gotowy na visio beatifica, gotowy zamieszkać w domu Ojca. Jest też zdolny do spełniania czynów Chrystusowych, czyli zasługujących, budujących Kościół. Pewną paralelę stanowi tu przykład Elizeusza, który okryty płaszczem Eliasza spełniał czyny podobne do swego mistrza: płaszcz towarzyszył działaniu z tą samą mocą Bożą, która towarzyszyła wielkiemu prorokowi. Przypowieść o synu marnotrawnym daje do zrozumienia, że ktoś okryty płaszczem łaski nie może już być niewolnikiem.

Idea przyobleczenia się w łaskę daje się rozpoznać w miejscach, w których Pismo Święte mówi o szacie, którą winni założyć zaproszeni na ucztę (por. Mt 22, 12; Ap 19, 8n). Szata ta świadczy o wewnętrznej czystości i pięknie duchowym uczestników Godów Baranka.

Łaska w Biblii jest przestawiana za pomocą alegorii światła. To właśnie jasność nawiedziła Szawła na drodze do Damaszku. Światło to manifestacja Boga, który przenika i uszlachetnia ludzkie wnętrze. Nowy Testament wiąże symbol jasności z życiem, z Chrystusem, który przychodzi jako życie i światło (por. J 1, 9). Dlatego światło 
okazuje się jedynym płaszczem godnym Maryi ${ }^{20}$. Niewiasta „obleczona w słońce" (Ap 12, 1) jest pełna łaski, tj., w najwyższym stopniu pełna życia od Boga i najbliższa Chrystusowi.

\section{II.4. PRAWDA O BOGU I JEGO ZAMIARACH}

W darze łaski Bóg ukazuje się taki, jaki jest: nieskończenie hojny, dobry i łaskawy. Udziela swojego życia darmo, bez uprzednich zasług i nadobficie. Nie ukrywa swoich zamiarów. Przeciwnie, zaprasza do współdziałania, a to znak wybrania i zaoferowanej przyjaźni. Bóg objawia swoje zamiary i ufa obdarowanemu.

Maryja, pełna łaski, nie przyjmuje biernie słów zwiastowania. Rozważa je według swoich ludzkich możliwości, chce poznać znaczenie tego, co usłyszała (por. Łk 1, 29). Bóg nie posługuje się rozkazem. $\mathrm{W}$ formie przyjacielskiego dialogu przekazuje swoje zaproszenie do współdziałania. Anioł zapewnia Maryję, że nie ma powodu do lęku, nawet tego wynikającego z poczucia wielkości Boga i własnej przygodności (por. Łk 1, 30). Nieskończona przepaść dzieląca Stwórcę od stworzenia została zniwelowana od strony Boga, który chce radować człowieka swoją bliskością. ,Znalazłaś łaskę u Boga” (Łk 1,30) - to zapewnienie o niepokalanym poczęciu, o zbawieniu „dokonanym w sposób wznioślejszy”. Maryja nie musi się obawiać, bo nie dotyczy Jej sytuacja, gdy człowiek lękał się bliskości Boga, ponieważ zasługiwał jedynie na śmierć (por. np. Kpł 16, 13; Lb 4, 19). W momencie zwiastowania ujawnia się to, że Bóg przychodzi jako Zbawca.

„Znalazłaś łaskę u Boga”, czyli człowiek nie musi już lękać się Boga, ani odczuwać przepaści swojej stworzoności. Nie ma powodów, by obawiać się tego, czego boi się ludzkość: zniszczalności i śmierci. „Znalazłaś łaskę” wybrania, zbawienia, obecności Boga. Łaskę trwałą i pewną, bo Pan jest z Tobą, Dawca życia.

Bóg zaprasza Maryję do uczestniczenia w Jego dziele. Zapowiedź: ,poczniesz i porodzisz”, to zaproszenie, aby i Ona była z Nim

${ }^{20}$ Por. J. K róli k ow s k i, Bogiem sławiena..., dz. cyt., s. 44-46. 
w dziele zbawienia. „Pan jest z Tobą”, to zapewnienie Bożej asystencji w tym, co szczególnie trudne. Rozmowa $\mathrm{z}$ archaniołem ujawnia tajemnicę serca Maryi; to, co otrzymała i pielęgnowała jako dar. To nie Ona pragnie dla siebie zaszczytu Bożego macierzyństwa, to Bóg Ją wybiera.

Niepokalana poznaje prawdę o Bożym ojcostwie, o Chrystusie Zbawicielu, Synu Boga, o celu Jego przyjścia (por. Łk 1, 32n). Łaskawość i szczodrość Boga przejawia się również w tym, że Stwórca nie ukrywa swoich zamiarów. Ujawnia je po przyjacielsku (por. J 15, 15). Chce, by człowiek mógł je podjąć w sposób wolny, świadomy i z radością, by coraz bardziej otwierał swoje serce na poznanie tego, w czym Bóg mu pozwala uczestniczyć.

Bóg udziela się jako Trójca. Ujawnia swoje zamiary i daje poznać siebie. Dzięki Ananiaszowi Szaweł słyszy o Jezusie i o Duchu Świętym (por. Dz 9, 17). To Duch Święty napełnia człowieka tak, by w wewnętrznym sanktuarium osoby dopełniło się Chrystusowe wezwanie. Podjąwszy współdziałanie z Panem, napełniony Duchem Świętym, już nie Szaweł a Paweł może zachęcać: „Weselcie się nadzieją" (Dz 12, 12).

\section{II.5. WOLNOŚĆ W PRAWDZIE}

Łaska to skierowany do osoby dar przyjaźni, nie jakiejś bezosobowej mocy czy energii. Wolność i prawda to podstawowe wektory określające dynamizm osób stworzonych na podobieństwo Boga. Spotkanie ze Stwórcą, przyjęcie Jego daru, udział w Jego życiu i wzrost świętości nie może odbywać się inaczej jak w wolności i prawdzie. Wartości te nie pochodzą z zewnętrznych warunków, ale tworzą wewnętrzny kształt człowieczeństwa. Od ich harmonii zależy trwanie i wzrost duchowy osoby.

Scholastyka przy omawianiu tematu łaski brała pod uwagę władze duchowe: rozum i wolę. Szanując osiągnięcia przodków, można za Janem Pawłem II przerzucić akcent na wolność i prawdę jako konstytutywne właściwości osoby (por. FR 90). To one stanowią strukturalną podstawę więzi Boga z człowiekiem, więzi, która przecież wynika 
z samoudzielania się Stwórcy. Bóg, który jest Prawdą i Miłością, nieskrępowaną Komunią Osób, Bóg Stwórca zwraca się do człowieka, który odpowiada w sposób wolny. Nieporozumieniem, w jakie uwikłały się choćby dyskusje banezjanistów z molinistami, byłoby podejrzewanie, że Bóg przymusiłby kogokolwiek lub zwiódł jakąś „socjotechniką", czyli że działałby wbrew wolności lub prawdzie.

Boża przychylność kieruje się ku ludzkiej wolności. Maryja to człowiek doskonale piękny w harmonii wolności i prawdy. Anioł zwraca się do Niepokalanej, afirmując Jej wolność. Bóg mógłby rozkazywać swojej Służebnicy, ale pragnie Jej własnej decyzji. Obdarowując, oczekuje nieskrępowanego daru z siebie.

W chwili zwiastowania Maryja jest już pełna łaski. Trwa „od początku” w komunii z Bogiem. Jednocześnie coraz bardziej odkrywa prawdę i wzrasta w miłości, bo i miłość, i prawda mają walor nieskończoności. Odczuwa wielkość swojego powołania i niezmierzoną wielkość Boga. Wie, kto się do Niej zwraca. Jest od początku zjednoczona z Tym, który wypełnia Jej serce. Nie pyta: „Kim jesteś?”, jak Szaweł pod Damaszkiem, dla którego był to dopiero początek drogi łaski.

Zwiastowanie przebiega drogą wolności i prawdy. Maryja zwierza się aniołowi ze swoich wątpliwości, z tego, co stanowiło najbardziej intymną treść Jej życia (por. Łk 1,34). „Pełna łaski” nie obawia się Boga. Okazuje zaufanie i oczekuje wykładni dotyczącej tego, co dla Niej najważniejsze. Od tego, co usłyszy, uzależnia swoje życiowe decyzje. Zostaje wprowadzona w głębię prawdy o Bogu, o Jego zbawczej łaskawości i konsekwencji w dopełnianiu swego dzieła. Anioł oczekuje Jej odpowiedzi. Jej wolność staje się w tym momencie punktem krytycznym zbawienia świata. Czym jest łaska zbawienia? W spotkaniu Maryi i archanioła okazuje się przebiegać drogą zaufania Boga do człowieka. Jest nie tyle łamiącą opór wszechmocą, ile nieskończonym zaufaniem, takim, na jakie stać tylko wszechmoc Stwórcy. Tak Bóg ufa ludzkiej wolności i tylko Bóg tak ufa. Wysyła Ducha Świętego, który jest w nas wewnętrzną 
zasadą zaufania Boga do człowieka ${ }^{21}$. W momencie „pełni łaski” ukazuje się niejako przeciwieństwo mechanicystycznych sporów o łaskę skuteczną i wystarczającą 22 .

Bóg łaskawy traktuje człowieka jako osobę; jako kogoś godnego prowadzenia dialogu. Nie rozkazuje. Wyjaśnia. W swojej przychylności odwołuje się do ludzkiej wolności i godności. Zaprasza do dialogu i refleksji.

Dociekanie prawdy przez Maryję powoduje objawienie tym większe; anioł mówi o Duchu Świętym (por. Łk 1, 35). Maryja doświadcza Trójcy. Gdy daje odpowiedź: „Niech mi się stanie”, wie, komu odpowiada. Poznaje dobroć i cierpliwość łaskawego Boga. Doświadcza niezwykłego szacunku, z jakim Stwórca odnosi się do stworzenia. Odkrywa swoją godność. W ten sposób łaska wspiera wolność i ubogaca ją prawdą.

Poczęta bez grzechu, okazując, że jest i chce być całkowicie zależna od Boga, daje w istocie wyraz pełnej wolności (por. Łk 1, 38) ${ }^{23}$. Struktura łaski jest bowiem taka, że gdy ktoś akceptuje pełną zależność od Boga, czyni go to wolnym wobec stworzeń. Natomiast prawdę o własnej zależności od Boga akceptuje się w miłości, ponieważ obdarowanie istnieniem pochodzi z Bożej łaskawości i dobroci. „Tak” Maryi jest owocem łaski, która nie tylko nie umniejsza wolności, ale przeciwnie - stwarza ją i podtrzymuje jej rozwój ${ }^{24}$.

W osobie Maryi widać wzorczą syntezę wolności i łaski. Pełna łaski jest pełna wolności; bez lęku wybiera większe dobro dzięki udzielającemu się Jej Bogu ${ }^{25}$.

${ }^{21}$ Por. G. L. Mü 11 e r, Katholische Dogmatik. Für Studium und Praxis der Theologie, Freiburg, Basel, Wien, 1996, s. 811.

22 Por. Breviarium fidei..., dz. cyt., VII, 128 - 129.

23 Por. B e n e d y k t XVI, Homilia, Lourdes, Prairie, 14 września 2008 r.; http://w2.vatican.va/content/benedict-xvi/pl/homilies/2008/documents/hf_ben-xvi_hom_20080914_lourdes-apparizioni.html.

${ }^{24}$ Tenże, Homilia podczas Mszy św. przed sanktuarium świętego domku laterańskiego,4 października 2012 r.; http://w2.vatican.va/content/benedict-xvi/pl/ homilies/2012/documents/hf_ben-xvi_hom_20121004_loreto.html.

${ }_{25}$ Por. J. K róli k o w s k i, Bogurodzica Dziewica..., dz. cyt., s. 256. 
Wiara jest łaską. Przykład Maryi pokazuje, że akceptacja łaski oznacza posłuszeństwo wiary (RM 26). To Duch Święty uczynił Jej serce doskonale posłusznym wobec samoudzielania się Boga. Otwarcie względem tego samoudzielania się Trójcy w Duchu Świętym to właśnie wiara (por. DeV 51). Natomiast otwarcie się Bożej głębi wobec człowieka daje pełnię wolności.

W idealnej harmonii prawdy i wolności, dzięki łasce Maryja bez lęku oddaje swoje życie do dyspozycji Zbawiciela. Niepokalana posiada siebie w totalnym wyrzeczeniu się dla Boga. Łaskawa interwencja Stwórcy wydoskonala bowiem wolność i odpowiedzialność ${ }^{26}$. Sprawia, że Służebnica Pańska jest panią własnej stworzoności. Łaska świętości, która wypełnia byt Maryi, w żaden sposób nie umniejsza Jej osobowości. Przeciwnie, czyni Ją tym bardziej mężną, niepowtarzalną i piękną w harmonii wszystkich ludzkich możliwości. Niezależna od wszystkiego poza Bogiem, Służebnica Pańska staje się Królową świata.

Udzielający się Bóg traktuje każdego z dobrocią i uszanowaniem struktury osoby. Szaweł słyszy polecenie pójścia do miasta, ale przecież nie zostaje przymuszony. Jest potraktowany jako sprzymierzeniec tego, którego do tej pory prześladował (por. Dz 9, 6). Czy już w tym momencie może się uważać za Jego przyjaciela (por. J 15, 15)? Ma czas na podjęcie decyzji. Nie pozostanie w nieświadomości. Powiedzą mu, co ma czynić (por. Dz 9, 6). Jeżeli pójdzie do miasta, dowie się, czego oczekuje od niego Jezus. Będzie mógł świadomie się zaangażować w spełnianie woli Zbawcy; w to, co ma stanowić kontynuację powstania z ziemi na wezwanie Pana.

Również Korneliusz otrzymuje polecenie. Ma wezwać Piotra (por. Dz 10, 5). Wysłanie ludzi po Apostoła to jego odpowiedź na zaofiarowany dar łaski. Podejmuje to wezwanie chętnie, w sposób wolny, już po zniknięciu anioła. W scenie zwiastowania Maryi anioł czeka na Jej słowo. Maryja nie potrzebuje czasu, ani dystansu na zastanawianie się. Jest pełna Boga. Inaczej Korneliusz i Szaweł. Po ustaniu niezwykłych zjawisk mają czas na swobodne rozważenie, decyzję

\footnotetext{
${ }^{26}$ Por. J. K róli k ow s k i, Bogiem sławiena..., dz. cyt., s. 314.
} 
i zaangażowanie się w to, co usłyszeli. Bóg nie chce, by działali pod wpływem wrażeń i emocji. Korneliusz akceptuje dar. W efekcie tego „Duch Boży zstąpił na wszystkich, którzy słuchali słowa” (Dz 10, 44). Słowo prawdy o Chrystusie i wewnętrzne działanie Ducha Świętego spotykają się i przynoszą owoce.

\section{II.6. WSPÓŁDZIAŁANIE W MIŁOŚCI}

Bóg w swojej przychylności zaprasza do podjęcia drogi łaski, czyli zaangażowania się w zbawcze dzieło. Człowiek daje Bogu odpowiedź w sposób wolny. Współpraca z łaską odbywa się w porządku trynitarnym, jako wyraz zamieszkania Boga w ludzkim sercu.

Maryja jak nikt inny żyje na sposób nowy, w nowości odkupionego człowieczeństwa. Żyje w obecności Chrystusa, w wewnętrznym zjednoczeniu z Nim i w mocy Ducha Świętego, która przecież nie odstępuje Jej po wcieleniu. Zażyłość z Chrystusem prowadzi Ją do coraz głębszego poznawania tajemnicy Ojca (por. RM 17). To Duch Święty uzdalnia Maryję do pójścia za Jej Synem. Łaska Ojca posyłającego Ducha Świętego jest nieustannie dopełniana przez więź z Jezusem ${ }^{27}$. Pełnia łaski to szczególna predyspozycja do współdziałania z Chrystusem (por. RM 39). Serce Maryi pracuje w doskonałej harmonii z Synem. Benedykt XVI przypomina o cnotach teologalnych, którymi Duch Święty ubogacił Maryję ${ }^{28}$. Pełna łaski wyśpiewuje Magnificat,

27 Por. B e n e d y k t XVI, Marian vigil for the conclusion of the month of May, address of his Holiness, Grotto of Our Lady of Lourdes in the Vatican Gardens, Feast of the Visitation of the Blessed Virgin Mary, Thursday, 31 May 2007; http:// w2.vatican.va/content/benedict-xvi/en/speeches/2007/may/documents/hf_ben-xvi_spe_20070531_mese-mariano.html.

${ }^{28}$ Por. B e n e d y k t XVI, Marian vigil for the conclusion of the month of May, address of his Holiness, Vatican Gardens, Saturday, 30 May 2009; http:// w2.vatican.va/content/benedict-xvi/en/speeches/2009/may/documents/hf_ben-xvi_spe_20090530_mese-mariano.html. 
bo to Duch Święty daje Jej wewnętrzne poznanie wielkości Boga. Oddanie Mu chwały to czyn łaski - wyraz wdzięczności ${ }^{29}$.

Maryja jako pełna łaski wkroczyła w ślady Syna - w dzieje zbawienia. Napełniona Bogiem jest"zwierciadłem", w którym oglądamy misterium Trójcy (por. RM 25). Wartość czynu zasługującego, efektu współpracy z łaską, zależy od zawartej w nim miłości. To ona stanowi w ludzkim postępowaniu vestigium absolutnej bezinteresowności Boga. Maryja, jak nikt inny, pokazuje, że człowiek zbawiony jest chwałą Stworzyciela. Całe Jej istnienie głosi moc łaski ${ }^{30}$. W Niepokalanej rozpoznajemy znak ostatecznego zwycięstwa miłości ${ }^{31}$. To wewnętrzna jedność z Jezusem sprawia, że Jego miłość wobec ludzi jest także Jej miłością (por. RM 21). Dzięki temu Maryja staje się nam Matką w porządku łaski; wprowadza w zasięg zbawczej mocy Chrystusa (por. RM 22).

Duch Święty powoduje, że człowiek działa w mocy Ojca (por. Łk 1, 33). Tak było np. w przypadku św. Szczepana, o którym Dzieje Apostolskie mówią, że czynił znaki pełen łaski i mocy (por. Dz 6, 8). Maryja - pełna łaski - uczestniczy w dziełach Boga, które dla człowieka byłyby niemożliwe do spełnienia (por. Łk 1, 37).

W chwili wcielenia Chrystus stał się obecny w Jej życiu. O Niej samej św. Jan Paweł II powie, że była odwiecznie obecna w tajemnicy Odkupiciela (por. RM 19). W ciągu swojej ziemskiej drogi zjednoczyła się tak z Jego zbawczym misterium, że mogłaby za św. Pawłem powiedzieć: „Żyję już nie ja, ale żyje we mnie Chrystus” (por. Ga 2, 20). Syn Boży ogarnął Jej byt całkowicie swoją tajemnicą i włączył

29 Por. B e n e d y k t XVI, Marian vigil for the conclusion of the month of May, address of his Holiness, St Peter's Square, Feast of the Visitation of the Blessed Virgin Mary, Saturday, 31 May 2008; http://w2.vatican.va/content/benedict-xvi/en/ speeches/2008/may/documents/hf_ben-xvi_spe_20080531_mese-mariano.html.

${ }^{30}$ Por. J. K róli k ow s k i, Bogiem stawiena..., dz. cyt., s. 43.

${ }^{31}$ Por. B e n e d y k t XVI, Homage to the Immaculate at the Spanish steps, address of his Holiness, Solemnity of the Immaculate Conception of the Blessed Virgin Mary, Monday, 8 December 2008; http://w2.vatican.va/content/benedict-xvi/ en/speeches/2008/december/documents/hf_ben-xvi_spe_20081208_immacolata. html. 
Ją bez reszty we własne dzieło. Św. Tomasz zwraca uwagę na to, że łaska, którą cieszyła się Matka Boża, była od początku pełna, a jednak coraz większa, bo przecież dokonywało się w Niej utwierdzenie w dobru, a w końcu osiągnęła cel, który przewyższał jej ziemski $\operatorname{los}^{32}$. Paradoks? To przykład nieskończonej hojności i niewyczerpanej doskonałości udzielającego się Boga. Bóg obdarza sobą nieograniczenie i bez końca.

Współpraca z darem łaski, faktyczny wyraz współpracy z udzielającym się Bogiem, uczestniczenie w Jego dziełach okazuje się uszlachetnieniem i pełnią wolności. Ananiasz dowiaduje się, że dawny prześladowca i faryzeusz został wybrany „,na narzędzie”. Czy jednak Chrystus rzeczywiście wykorzystywał „instrumentalnie” Apostoła narodów? Wyjaśnienie znajdujemy w słowach samego Pawła: „pracowałem więcej od nich wszystkich, nie ja, co prawda, lecz łaska Boża ze mną" (por. 1 Kor 15, 10). Szczepan pełen łaski działał znaki i cuda. Prawda Chrystusa, podjęta, wyzwala do czynów Chrystusowych, tj., spełnianych wraz z Nim. Działanie łaski w duszy Matki Najświętszej uczyniło rzeczywistym Jej współudział w odkupieńczym wyniszczeniu Syna (por. RM 18). Cokolwiek zostało powiedziane w teologii o czynach zasługujących, znalazło wypełnienie w sercu Matki stojącej pod krzyżem. Współdziałanie z Bogiem zostaje nagrodzone łaską ostatecznego wytrwania. Maryja pod krzyżem słyszy dialog Ojca z Synem. Szczepan w momencie śmierci widzi niebo otwarte. Paweł, antycypując to, co stanie się z nim przy Tre Fontane, pisze; „dopełniam braki udręk Chrystusa” (Kol 1, 24). W ten sposób podjęty dar łaski, przyjęte zaproszenie do komunii życia Bożego, realizuje się w ostatecznej wolności ludzkiego bytu; wolności, która już nie obawia się śmierci.

Maryja, która przy zwiastowaniu usłyszała słowa: „Pan z Tobą”, może z pewnością powiedzieć: „Pan jest ze mną, nie lękam się” (Ps 118,7). Słowa psalmisty wyrażają tu obiektywną rzeczywistość łaski: Bóg jest przy osobie jako pewny Gwarant życia. Męstwo Maryi to więcej niż naturalna cnota. To heroizm wiary Pierwszej wśród

\footnotetext{
32 Por. STh III, q 27, a 5.
} 
świętych. „Pan jest ze mną, nie lękam się” może powtórzyć Maryja, ponieważ jest jak Syn, wraz z Nim i dzięki niemu niezłomna. „Tak” dane aniołowi, przyjęcie Bożej inicjatywy i wierne posłuszeństwo we współdziałaniu z Trójcą prowadzi do zwycięstwa nad śmiercią. Pełna łaski jest wniebowzięta ${ }^{33}$.

\section{II.7. EKLEZJALNE SKUTKI LASKI}

Przypowieść o synu marnotrawnym uczy, że uzyskane od ojca przebaczenie przywraca nawróconego nie tylko ojcu, ale także starszemu bratu, a więc przyczynia się do odnowienia wspólnoty. Łaska przynosi skutki eklezjalne. Boża inicjatywa zostaje dopełniona w Kościele, przez Kościół i owocuje dla Kościoła. Maryja stała się Matką Kościoła dlatego, że współpracowała z dziełem Zbawiciela (por. KK 61). Spełniły się Jej natchnione słowa, że wszystkie narody będą nazywać Ją błogosławioną. Szaweł staje się Pawłem i uczniem Chrystusa dlatego, że niezwykłe zdarzenie z podróży do Damaszku zostało dopełnione spotkaniem z Ananiaszem, który uznał w nim brata (por. Dz 9, 17). Dzięki otrzymanej łasce Paweł staje się Apostołem narodów. Objawienie dane Korneliuszowi domaga się sprowadzenia Piotra. W efekcie postawy setnika Duch Święty zstępuje na wszystkich, których zgromadził w swoim domu (por. Dz 10, 44). Bóg nieskończenie hojny jest komunią Osób. Udziela swego życia tworząc wspólnotę.

Zbawcze udzielanie się Boga osiąga swój punkt kulminacyjny we wcieleniu. To szczyt obdarowania łaską w dziejach kosmosu (por. RM 9; DeV 50). Maryja pełna łaski - niesie w sobie moc Bożej miłości, której nie zatrzymuje dla siebie. Bóg zechciał Ją włączyć w dzieło zbawienia. Ta, która ma przy sobie Boga Wspomożyciela, może być Wspomożeniem wiernych. Pełna łaski staje się pośredniczką

33 Por. Benedykt XVI, Holy mass on the solemnity of the Assumption of the Blessed Virgin Mary, Homily if his Holiness, St Thomas of Villanova Parish, Castel Gandolfo, Sunday, 15 August 2010; http://w2.vatican.va/content/benedict-xvi/en/ homilies/2010/documents/hf_ben-xvi_hom_20100815_assunzione.html. 
łask - dóbr zbawczych i łaskawą Matką Kościoła. Błogosławieństwo, które otrzymała z miłości trynitarnej jest przecież za sprawą Jezusa skierowane do całej ludzkości (por. RM 8). Maryja pełna Ducha Świętego jawi się przedstawicielką wszystkich ludzi, jedyną godną tego, by Bóg mógł Jej w pełni udzielić swego życia i w Niej „poślubić ludzkość"34. Jej doskonałość niejako otwiera drogę Zbawicielowi, a zarazem stanowi zalążek dobra Kościoła i całego stworzenia.

\section{ZAKOŃCZENIE}

Bóg nie udziela tylko czegoś, ale siebie. Zaprasza do wspólnoty z sobą, do udziału w Jego własnym, życiu. Bez końca. Ostatnie słowa Apokalipsy zapewniają o niepodważalności daru: „Łaska Pana Jezusa z wami wszystkimi”. (Ap 22, 21). Bóg nieskończony w łaskawości nie ustanie w udzielaniu życia. Jego przychylność jest niezmienna i skuteczna. Skierowany do osób dar życia zapewnia nie tylko wyzwolenie $\mathrm{z}$ grzechu, ale i trwałą moc w zmaganiach towarzyszących Kościołowi. Bóg Trójca zaprasza do wspólnoty z sobą przez Chrystusa. Ten, który jest Panem „napełnia wszystko wszelkimi sposobami" (Ef 1, 23); ma dostęp do głębi dusz, do najskrytszego wnętrza osoby. Działa przez Ducha Prawdy, który w ludzkim sercu buduje więź z Bogiem na kanwie wolności i prawdy. Te właśnie wątki odnajdujemy w nauczaniu współczesnych papieży, św. Jana Pawła II i Benedykta XVI, a osobowym wzorcem najdoskonalszego życia łaski jest Maryja - pełna łaski.

\section{Gracious God. Towards more personalistic charitology Summary}

The theology of grace focuses on God's self-giving. In this mystery God gives not a thing but Himself. He invites human being to participate in His trinitarian life and makes this possible. The teaching of contemporary Popes - St. John Paul II and Benedict XVI involves the personalistic issues while dealing with the mystery of

${ }^{34}$ Por. J. K róli k o w s k i, Bogurodzica Dziewica..., dz. cyt., s. 189n. 
grace. In this personalistic language is spoken rather about choice of person than (pre-)destination. The response for God's gift comes from reason and will, but it's pointed that it goes through paths of truth and freedom.

Biblical examples show the rules of God's grace. These are: Mary - full of grace, Paul and Cornelius. These cases present the intrinsic way of God's self-giving. It's to realize that the mystery of grace reveals the truth about the condition of person who is to accept the gift of salvation. In the light of the Holy Spirit one learns clearly about the God's intentions and is invited to follow them. The grace acts in the light of the truth and gives an impulse to freedom. It can be accepted only voluntarily, is fulfilled within the Church and brings ecclesial fruits.

Slowa klucze: łaska, Trójca Święta, wzorzec, Maryja, Paweł, Korneliusz

Key words: grace, Holy Trinity, pattern, Mary, Paul, Cornelius

Skróty: Benedykt XVI: CiV - Caritas in veritate, DC - Deus caritas est, VD Verbum Domini; Jan Paweł II: DM - Dives in misericordia, DeV - Dominum et vivificantem, FR - Fides et ratio, NM - Novo millenio ineunte, RH - Redemptor hominis, RM - Redemptoris Mater,; DA - Dekret o apostolstwie świeckich Apostolicam actuositatem; KDK - Konstytucja Duszpasterska o Kościele Gaudium et spes, KL - Konstytucja o Liturgii Sacrosanctum concilium; STh -Suma teologiczna św. Tomasza z Akwinu

Nota 0 autorce: dr hab. Izabella Smentek (UKSW), w podejmowanych badaniach koncentruje się na eschatologii, trynitologii, eklezjologii, a także nauczaniu Jana Pawła II i Benedykta XVI

\section{Bibliografia:}

Głowa S., Bieda I. red., Breviarium fidei. Wybór doktrynalnych wypowiedzi Kościoła, Poznań 1989.

Jan Paweł II, Homilia z 16.06. 1999, w: red. J. Górny, VII pielgrzymka Jana Pawta II do ojczyzny, Olsztyn 1999.

Jan Paweł II, Trzecia pielgrzymka Jana Pawła II do Polski. Przemówienia, dokumentacja, Poznań - Warszawa 1987.

Kijas Z., Traktat o Duchu Świętym i łasce, w: E. Adamiak, A. Czaja, J. Majewski (red.), Dogmatyka. T. 4, Warszawa 2007, s. 512n.

Królikowski J., Bogiem stawiena Maryja, Niepokalanów 2015.

Królikowski J., Bogurodzica Dziewica, Niepokalanów 2013. 
Müller G. L., Katholische Dogmatik. Für Studium und Praxis der Theologie, Freiburg, Basel, Wien 1996.

Rahner K., Grundkurs des Glaubens. Einführung in den Begriff des Christentums, Freiburg im Breisgau 1976.

Tomasz z Akwinu, Kęty 1999.

Wojtyła K., Aby Chrystus się nami postugiwat, Kraków 1979.

Wojtyła K., Osoba i czyn, Kraków 1969. 